\title{
A Cultural Approach to Translating the Forgotten Legacy of the Egyptian Folk, A Case study of Mawwal Badriya
}

\author{
Dr. Yousreya Ahmed Ali Alhamshary \\ Lecturer of Applied linguistics \\ English department, Faculty of Education, Damanhour University \\ e-mail:alhamshary@edu.dmu.edu.eg
}

\begin{abstract}
For language is a cultural construct, certain cultural untranslatability is implied in any process of translation. Cultural problems may occur mainly in the translation of socio - cultural topics, especially in case of sophisticated literatures like, proverbs, folk, myths, satire, humour, etc and especially in relation to idioms, images similes and metaphors. One of the areas full of figures is the public Egyptian folk "Mawwal" in which there is one unique life of Egyptian society. This type of literary work is chosen due to its great role in formulating the Egyptian identity in the 60s and 70s. The present paper attempts to examine some strategies in non-equivalence translation, and finds out cultural problems. The data is collected from the recorded song entitled Badreya, transcribed into Arabic then translated into English. Translation strategies for dealing with non-equivalence proposed by Baker (1992) are applied as a theoretical framework for the research. Results show some cultural problems and some strategies of translation are focused on this study.
\end{abstract}

Key words: Egyptian folk, culture-specific translation, translation and equivalence, translation problems. 


\section{ترجمة الإرث المنسي للأغنية الصرية (الموال) ، صعوبات التزجمة}

\section{واستراتيجياتها: دراسة خاصة لموال بدرية}

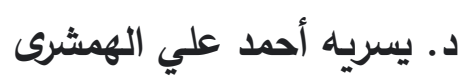

مدرس اللغويات التطبيقية- قسم اللغة الانجليزية- كلية التربية - جامعة دمنهور

$$
\text { الملخص العربي للاراسة }
$$

تتطوى عملية الترجمة ضمنيا علي بعض التعبيرات الثقافية الغير قابلة للترجمة,

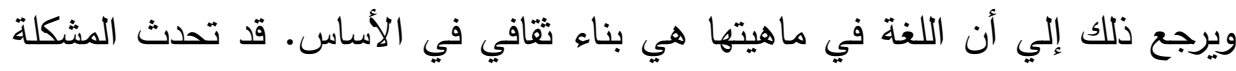

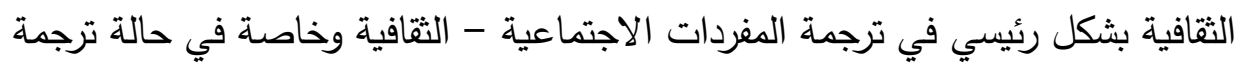
الأدب المتطور مثل المصطلحات والأمثال والصور والتشبيهات الثبعبية والأساطير

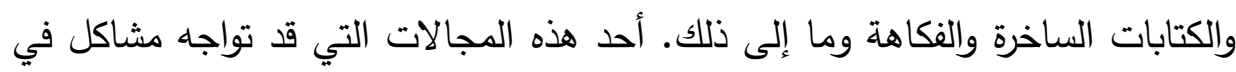
الترجمة هو ترجمة الغناء الثعبى "الموال". تشمل الموال واقع حياة فريدة من نوعها في

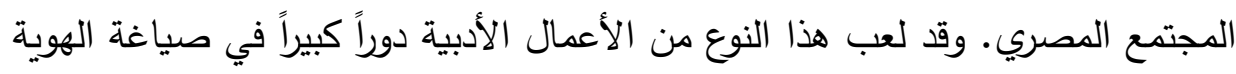

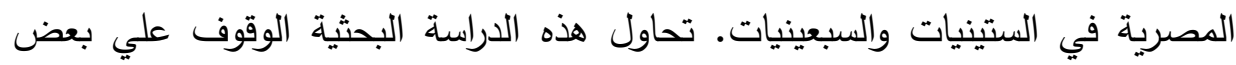
الاستراتيجيات في ترجمة المفردات الغير متكافئة، ومعرفة المشكلات الثقافية الغير قابلة

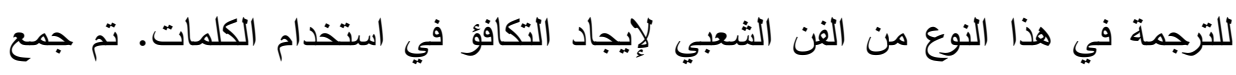
البيانات من محتوى صوتى نادر بعنوان "بدرية" التي يؤديها فنان يحمل اسم "أبو درع" تم لت

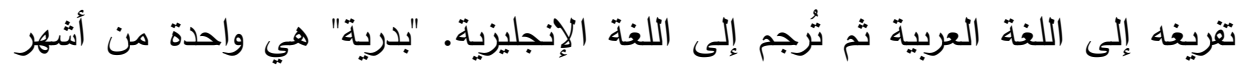

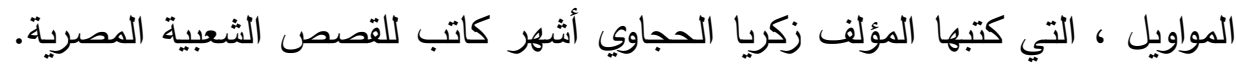
تميز أبو درع - مغني الموال - عن غيره بموهبة الارتجال في غناء الألحان الثعبية.

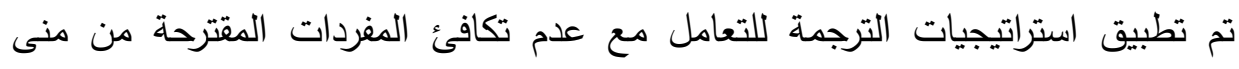
بيكر Mona Baker (1992) كإطار نظري للبحث. ركزت الورقة الحالية بشكل

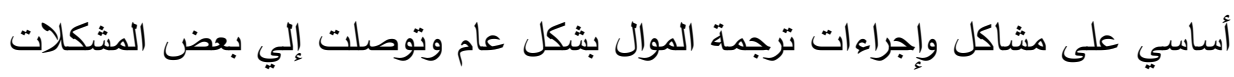
والعوائق في ترجمة هذا النوع من الغناء، بعضها يتعلق بالثقافة والآخر يتعلق بالبنية اللغوية لله.

الكلمات المفتاحية: مشاكل الترجمة- المشكلات الثقافية- الموال- الفن الثعبي 
A Cultural Approach to Translating the Forgotten Legacy of the Egyptian Folk, A Case study of Mawwal Badriya

Dr. Yousreya Ahmed Ali Alhamshary

مجلة وادي النيل للاراسات والبحوث الإنسانية والاجتماعية والتربوية (مجلة علمية محكمة)

\section{Introduction}

Translation nowadays is considerably important, especially in an increasingly globalized world. Translation offers and paves the way into other cultures, a way that illuminates both the similarities and differences of the world's people and introduces new concepts and viewpoints to formulate national cultures. It is highly important for science and technology because increasing amounts of research are conducted in transnational networks of scientists and technicians who need to communicate accurately in their fields. In addition, it affects peoples' viewpoints and life experience, because it allows us to have insight into other peoples' lives, sometimes opening whole new perspectives and allowing unforeseen opportunities for empathy and understanding. Translation is very important to the business world too. Through translation, we gain knowledge of international laws, the news in other countries etc. Translation facilitates daily communication between people from different countries. Since each language reflects its own history and culture, a translator can successfully convey the cultural context and enhance the mutual understanding between two cultures through good translation. Translation contributes so that human being has common references, like the translation of the Bible, or translation of the literary works of famous writers like Mahfuz. Thus, translation is a very important matter to exchange culture, science, technology, languages, and perspectives. It is true with translation we are a part from the world and a lot of history is protected from being destroyed or deformed. Therefore, translators should have perfect background about both source language and target language. Consequently, the most important problem concerning these different thoughts is the lack of equal terms from SL to TL.

Thus, translation typically has been used to transfer written or spoken SL texts to equivalent written or spoken TL texts. In general, the purpose of translation is to reproduce various kinds of texts-including religious, literary, scientific, and philosophical texts - in another language and thus making them available to 
wider readers. The history of any society starts from the folk which is an integral part of the identity and history of any society. The Egyptian folk is one of the richest sources for values and principles of the old Egyptian family life. Wishing to shed light to this type of written literary work and its related social life, the researcher handled this song to reflect on this part of time and life of Egypt by translating this song "Badreya" as will be illustrated in the following lines.

\section{Theoretical Background}

During the Egyptian revolution in 2011, some undesirable behaviors emerged from the people of the lower class. It is well known that the Mawwal is directed to this class and the middle one before. This art has ceased for a long time and no longer reflect the values of the society. During the time of this flourishing Mawwal it is also well known that social values are appreciated and reinforced in treatment and used to spread the noble values among people. Badreya is one of the most famous Mawwals, written by Zakreya Alhegawy, the most famous writer of folk stories. The Mawwal settings include one of the unique lives of Egyptians. Abu Daraa, the singer of Badreya, distinguished himself with the talent of improvisation in the singing of popular melodies. He kept the names of the attendees at the parties to present greetings to them each in his own name. Compared to others in this area very rare is available from his work as there is no documentation and he stopped to work in it. Cinema did not address any of his stories like his peers. Although he composed many of his writings, he did not attend school or study music. He was unique in Mawwal performance for long years. None of his followers were able to complete after him for the difficulty of performance in this type of singing. He was distinguished from other participations in the period of Egyptian revolution for the large number of contributions in the national songs, including (Helit Ya Gamal - Spring Festival O Jamal beauty beautiful - Candles freedom ... etc). However, he has been absent from the national singing scene so far. Art has been employed in that period for the development and renaissance 
A Cultural Approach to Translating the Forgotten Legacy of the Egyptian Folk, A Case study of Mawwal Badriya

Dr. Yousreya Ahmed Ali Alhamshary

مجلة وادي النيل للاراسات والبحوث الإنسانية والاجتماعية والتربوية (مجلة علمية محكمة)

of the Arab people in general, and Egypt in particular. Because Mawwal addresses the vast majority of the people, the government in the 1950s did publish and support the dissemination of this art. Zakaria Hijjawi utilized these voices to disseminate political awareness, as well as social and human values. The creativity lies in the content, especially in this story where one finds noble values and details about the reality of injustice life experienced by the simple Egyptian people.

Badreya is chosen for the research because of the richness in history, its marvelous language and social values representing the Egyptian life in the 60s and 70s. Because it is so unique and many of the concepts included are bound to Egyptian culture, the translation may face some problems. This Mawwal is full of social and ethical values that the writer wishes to be in the society. Nowadays the Egyptian society suffers from the lack of these values like man loving his family and protecting women from violence as will be clear from the Mawwal. The researcher translates the stanzas and reports some problems with solutions. To make the translation of the text into English readable and as relative as possible, syntactic, semantic and pragmatic techniques are used based on strategies of Baker (1992).

Translation, according to Nida and Taber (1982), is a process of "reproducing in the receptor language the closest natural equivalence of the source language message, first in terms of meaning and secondly in terms of style". Translation theorists assert that translation of a literary text is a difficult task, particularly the translation of a text written in the form of poetry (Nida, 1964; Raffel, 1988; Newmark, 1991; Bassnett, 2002). When discussing the problems of correspondence in translation, "differences between cultures may cause more severe complications for the translator than do differences in language structure" (Nida, 1964: p. 130). In the 1970s there was a growing realization that literary texts are constituted not of language but of culture, language being just a vehicle of culture. Lorna Andre Lefevere (2000), one of the major translation scholars who linked 
translation with cultural studies, pointed out that in this way translation can be studied as one of the strategies cultures develop to deal with what lies outside their boundaries and to maintain their own character while doing so - the kind of strategy that ultimately belongs to the realm of change and survival, not in dictionaries and grammars. In the present research translating Mawwal is very important for restoring this kind of art that saves the social values and helps restoring the Egyptian ethical heritage.

Hardwick, (2000: 22) suggests that the act of translating words also 'involves translating or transplanting into the receiving culture the cultural framework within which an ancient text is embedded'. The act of translation involves wayward attempts at bridging two societies which are diverse linguistically and culturally. The hermeneutic context, would determine the quantity and type of translations that might be undertaken, and the status of those translations would be greater or lesser according to the position of the receiving culture. So a work could be fundamentally important in the source culture, and could then be translated and have no impact at all in the receiving culture or, vice versa, a translation could alter the shape of the receiving literary system. Finding the appropriate cultural equivalents is not always easy for languages expresses culture, that is why "translators should be bicultural, not bilingual" as stated by Bassenett and Lefevere (1990. P.11). Translation activities should be regarded as having cultural significance. The acquisition of a set of norms for determining the suitability of that kind of behaviour and for maneuvering between all the factors which may constrain it, is therefore a prerequisite for becoming a translator within a cultural environment. (Toury, 1995)

\section{Mawwal}

Egypt and the Egyptians' special character and remarkable ability to innovate has added a lot to the arts and literature and positioned the Egyptians as creators of the arts and literature. Every language has its especial way to perceive reality, which influences the way in which reality is expressed by the members of its community. The Mawwal starts up in Baghdad, but it is transferred and flourished in Egypt. Writers and poets excelled in 
A Cultural Approach to Translating the Forgotten Legacy of the Egyptian Folk, A Case study of Mawwal Badriya

Dr. Yousreya Ahmed Ali Alhamshary

مجلة وادي النيل للاراسات والبحوث الإنسانية والاجتماعية والتربوية (مجلة علمية محكمة)

using it in their poetry, so that they enjoyed it in terms of the popular Egyptian proverbs. It was common to use patience expressions in written texts, not in a sense of acceptance, but in a sense of its revolutionary feeling. The art of Mawwal in Egypt became an art of resistance, like that of "Adham Alsharkawy" and "Zahran". The main feature of Mawwal is that it deals with the simple and complex minds and hearts.

In her book "The character of Egypt", Ne'mat Fouad (1989), an Egyptian famous writer, mentioned the most important works of the Egyptian artists, who were inspired, influenced and developed to present this pure Egyptian folk literature in its original style. The Mawwal as a national Egyptian art, is written in words that are often unusual in some way to create a special effect on the listener. This special effect is manifested in music, words, and other creative elements which relate to each Mawwal performance individual context. Translating this type of Egyptian art is very important and at the same time is problematic because it involves translating the metaphorical or figurative meanings of texts that relate to a certain type of environment controlled by ethics and culture that may not be known to everyone.

In the 1919 Egyptian revolution, the Mawwal is heavily invested with the Egyptian masses and the artists of the period: Beram, Mahmoud Ramzi Nazim, Hussein Shafiq Al Masri, and Dr. Said Abdo, who is one of the pioneers of Egyptian finance with all its Egyptian artistic characteristics. Thus, Mawwal is a rich source to understand and a tool to unify the Egyptian society. The first one to employ it in songs was Mohamed Abdelwahab when he used Dr Saed Abdo's text expressing his sadness of being betrayed. Consequently, translation and culture are so interrelated that translators can no longer ignore cultural elements in a text. There is always a context in which the translation takes place, always a history from which a text emerges and into which a text is transported, always an individual (the translator) belonging to a particular culture or a social background and always a readership whom the translator has in mind. This particular Mawwal represent 
the feminine value in the Egyptian society and how the writer wishes that she is protected during the time of oppression against woman in the Arab society

As Baker (1992).points out, the advantage of "cultural equivalence" is that "it gives the reader a concept with which s/he can identify, something familiar and appealing", and likely to have a similar impact on the target reader. Finding the appropriate cultural equivalents is not always easy and "translators should be bicultural, not bilingual". As "there are no such things as identical equivalents" between different languages, Nida (1964), argues that any other translations can be taken into consideration.

Catford (1965) makes a distinction between linguistic and cultural untranslatability. Focusing on the question of what is untranslatable; he argues that linguistic untranslatability occurs when there is no lexical or syntactical equivalent in the TL. He saw cultural untranslatability as more complex and loosely formulated: something is culturally untranslatable when there is no equivalent situational feature in the source language.

A lot of studies are conducted in relation to translation equivalence and cultural problems but most of them are about English Arabic. Whereas, very rare are conducted in relation to Arabic English ones especially related to this type of folk (Mawwal). For Example, Kashgary (2011) points out that nonequivalence strategy may become more relevant than equivalence or "non-equivalence" becomes more equivalent than "equivalence; in translation of cultural Arabic text to English".

In his study Braçaj (2015) claims that the more a translator is aware of complexities of differences between cultures, the better a translator s/he will be. At the same time, Dauod (2017) in another study explores the different definitions of translation as a process and as a product as well. Her study focuses on specific definitions that have been introduced by Arab scholars in the field of translation. She concludes that translation is not a mere substitution of texts among languages. To continue exploring about the problems of translation, this research is conducted specially in the area of Mawwal. 
A Cultural Approach to Translating the Forgotten Legacy of the Egyptian Folk, A Case study of Mawwal Badriya

Dr. Yousreya Ahmed Ali Alhamshary

مجلة وادي النيل للار اسات والبحوث الإنسانية والاجتماعية والتربوية (مجلة علمية محكمة)

\section{Data and Methodology}

The difference between a SL (source text) and a TL (target text) and the variation in their cultures make translation process a real challenge. Among the problematic factors involved in translation are form, meaning, style, proverbs, idioms, etc. One of the aims of this paper is to shed light on the social life of the Egyptian society during the Mawwal time as part of the social and cultural identity of the Egyptians and represents some of emerged problems from translating it. Translation strategies for dealing with non-equivalence at word level proposed by Baker (1992) are applied as a framework for the data analysis. The data for the study are derived from the original audio of Egyptian national culture Mawwal. The translation process goes on considering the following: the poetic form of the Arabic song, the differences of language constructions between Arabic and English, and the socioculture of the source text and the target text. After Arabic text analysis comes the translation part where cultural words are translated. The other step in translation is the use of word-for-word translation where it is mainly employed to understand the mechanics of the source text and construe a difficult text as a pretranslation process. As a pre-translation process, the SL syntactical constructions are converted to their nearest TL equivalents but the lexical words are translated separately out of context. Semantic translation that translates less important cultural words by culturally neutral functional terms is used also in some points. Free translation (called paraphrase which is much longer than the original text or the content without the form of the original text) is reproduced in the translated text.

A framework in Baker is based on eight translation strategies, including; translation by a more general word (superordinate), translation by a more neutral/less expressive word, translation by cultural substitution, translation by using a loan word or loan word plus explanation, translation by paraphrase using a related word, translation by paraphrase using unrelated words, translation by omission, and translation by illustration. 
مجلة وادي النيل للاراسات والبحوث الإنسانية والاجتماعية والتربوية (مجلة علمية محكمة)

(ISSN : 2536 - 9555)

The work chosen for our analysis "Badreya" is selected by means of purposive sampling based on the endorsement of the viewers among a lot of videos for some singers. The Arabic version of the selected song is translated by the researcher and revised by two of my colleagues who are specialized in translation. The research analysis is limited to analyzing the translation of text only besides shedding light on the cultural side. Badreya is a representative sample of this art. The transcribed text is limited too to the colloquial Arabic and the translated text to standardized English not colloquial English.

\section{Data Analysis and Discussion}

The data of the original Arabic ballad (Mawwal) is formed of nineteen stanzas in Arabic poetry. This Mawwal represents a historical background and a full narrated story about the Egyptian society in the 70s where there was a lot of injustice and corruption in Egypt. The story is full of social values and principles at that time like educating women and family life importance represented by the main character of Abdelmegid as a family protector. The complexity of social life is very clear in the words and also the way of introducing it. The popular art (Alfan Alshaby) is representing Egypt for a long time but now songs and the style are deteriorated. That is because there is no control over human value or such arts like before; where it was a common approach in all arts to keep values and ethics. There is a big difference between what Abu Dara told the audience at one of his concerts in 1960 "not to shoot in the air, but more useful to keep bullets to the heart of the enemies of the Arab nation" if compared to current words that say "if you shoot I shoot".

Concerning the theme of the song, it deals with the rural social life. The characters in the song are seven divided into narrators (the singer and the Chorus) and the real characters of the song (five: Abdelmageed, Badreya, Shedid, Abdelqawi, and M'omena). The singer succeeds in giving a total image of their life and the social concepts and interaction. The music of the Arabic version (rhyme) in all the nineteenth stanzas that are translated into English in the same number of stanzas, goes as (a,a,a.b.b.b.a) except the first 
A Cultural Approach to Translating the Forgotten Legacy of the Egyptian Folk, A Case study of Mawwal Badriya

Dr. Yousreya Ahmed Ali Alhamshary

مجلة وادي النيل للاراسات والبحوث الإنسانية والاجتماعية والتربوية (مجلة علمية محكمة)

stanza goes as (a,a,a,b). However, in English they defer from one stanza to another in this musicality, which indicate a difficulty in committing to the rhyme of Arabic and at the same time keeping the Arabic meaning of sentences. Only four stanzas out of nineteen go with the Arabic music (a.a.a.b.b.b.a) they are number eleven, thirteen, fifteen, and nineteen. This is because of the commitment to the semantic meaning of the Arabic structure. The cultural aspects are recurrent around the Mawwal. Based on Baker (2018) they are translated as follows.

Stanza (1)

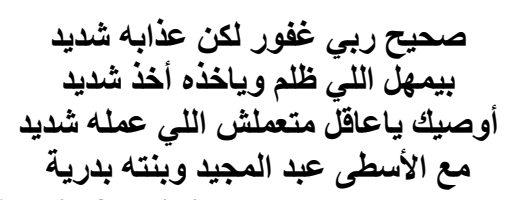

True that God is forgiving yet, He may punish awfully.

He may delay the oppressor Then, He seizes him painfully.

$O$ wise man! $O$ you! I advise you not to do

like what Shedid did with Mr Abdel Magid and his daughter Badreya, too.

The cultural aspects start from the first stanza. The word Shadid "شديد" lexically means "strong" is used with the meaning severe and sometimes as the name of a person is part of the rhyme in the stanza. This, in turn, can cause difficulty for the translator who has to keep the meaning and rhyme scheme. The word "اسطىى" is a title given with different meanings in colloquial Egyptian and can be translated into standard English using paraphrase to mean a master of the work, a professional, a tutor of the profession and sometimes an experienced manual manufacturer. Time division, jobs, positions and professions, food, drink, baking, particular aspects of social life, measurements, coins, institutions, clothing,... etc are all terms differentiate a community from another and are difficult to translate. Analyzing the source text lexical meaning; the researcher uses Baker's model where there are four main types of meaning in words utterances (prepositional meaning, expressive meaning, presupposed meaning and evoked meaning. The translator uses 
"Mr" simply to adapt with the English culture that does not have same expression. In the first stanza the word "shedid's" propositional meaning indicate the true punishment of God to the injustice people. Whereas the expressive meaning for the word "osta" is used here to reflect on the one who works as a dressmaker and lexically it has no meanings but usually used to express a job "driver". Colloquial Arabic is not matched by colloquial English. Consequently, Standard English is used. Mawwal, in nature is a lore that is based on colloquial Egyptian. It is directed towards simple people of low income and poor education. The nonequivalence of structure formation does not show the spirit of the text and is not favored as one obstacle faced by the translator.

Stanza (2):

As Hugh Kenner (1971) indicates that the translator's task "must be a sort of seeing. And once his grasp of the original emotion is firm and contextualized, neither it nor the version he arrives at are likely to wobble". Thus, the translation will succeed when the translator understands and respects what counts, or what is central to the particular work. For example:

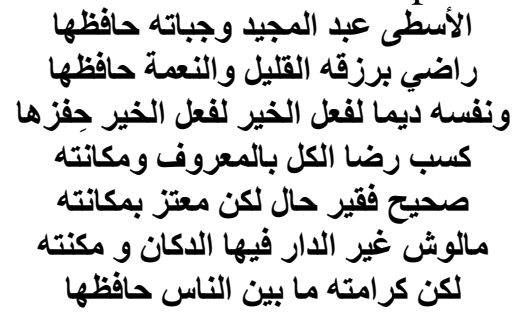

Mr Abdel Magid is, on his duties, an honest guard.

Content with his little income and does safeguard.

To do the good he always urges himself forward.

He is admired by all for his favors and dignity

It's true he is poor but he's proud of his dignity

He has nothing but a house with a shop where there's a sewing machine to help. Amongst people he protects his dignity.

The translators add some words to render the original meaning and make the translated text understandable. Here, the translator explained the meaning of machine to be (sewing one) not any other 
A Cultural Approach to Translating the Forgotten Legacy of the Egyptian Folk, A Case study of Mawwal Badriya

Dr. Yousreya Ahmed Ali Alhamshary

مجلة وادي النيل للار اسات والبحوث الإنسانية والاجتماعية والتربوية (مجلة علمية محكمة)

type .The translator's choice of words is always meant to stimulate the readers' reactions or feelings.

Addition means adding any text that is needed, such as a word, a phrase, or even a clause, to make the translated text seem natural, either semantically or grammatically, in the target text. The translation of some words can cause difficulty in rhyming as the meanings in English are not the same spelling in Arabic "راضي" Satisfied and approval " shows that the rhyme is not matched like "و "و جباته حافظها "مكانته ومكنته" are position and machine duties" النعمة حافظها "Mr Abdelmagid is an honest guard on his duties. He is pleased with his little income and does safeguard. Another example is the Arabic expression "كرامته حافظها", "dignity appreciated". Concerning the presupposed meaning the second stanza has the word "حافظها" as indicating keeping" or conserve. Whereas there are a lot of words expressing the evoked meaning like "دار" used for "house" not home that can be confusing to the reader and "دوكان" "shop" that do not represent the rural and social life as shop is any small shop to sell and buy but not a supermarket.

\section{Stanza (3)}

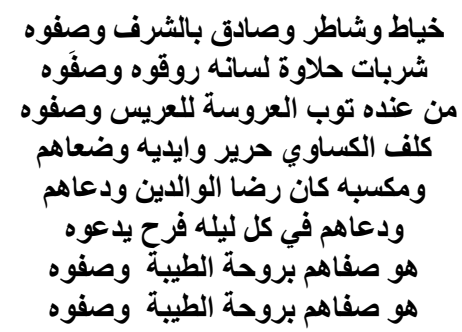

He's a clever tailor; truthful and known for honesty.

Sweet are his words; Like sherbet of high quality.

From his shop a groom is advised to buy the dress for his bride;

dresses with silky hand-made laces with nice decoration.

His gain was his parents' pleasure and their invocation.

At every wedding night he invites people and he accepts their invitation.

He befriended them with his good soul; And likewise they befriended him all.

He befriended them with his good soul; And likewise they befriended him all. 
مجلة وادي النيل للاراسات والبحوث الإنسانية و الاجتماعية والتربوية (مجلة علمية محكمة)

(ISSN : 2536 - 9555)

In the third stanza, there is a mixture of direct and indirect speech "From his shop a groom is advised to buy the dress for his bride","من عنده نوب العروسة للعريس وصفوه". Here the translator faces the problem of literal meanings where the denoting meaning is not the actual one. The cultural background in the translator says that he understand the process of getting the bride ready for marriage and buying things for her "كساوى" meaning the furniture of her house which is not known with this name in the English culture and translated as "buy the dress" which limited the concept to buying only dresses. The word "شاطر" can be translated with different expressions like "active" , "professional" or "clever" which can be to some extent confusing. At the same time the expression "شربات the literal translation is "syrup" but the actual required meaning is "so sweet". The word "شربات", "sharbat" is indicating a social custom meaning a sweet drink that all people have in happy occasions only but not a soft drink like Pepsi. However, in English they may have soft drinks in happy occasions or other drinks like wine which is in Arabic a shameful drink only corrupted people have it. Another cultural expression is " حلاوة "لسانه its literal meaning is "sweetness of his tongue", whereas the actual meaning is "polite speech" or people like his sweet words. The confusion caused by the literal meaning can be shown also in " is translated as "of high quality" meaning purified and clear."صفاهو "للعروس وصفوه" is advised", befriended". The structure used by the translator was mostly in the passive voice on the contrary to the Arabic structure which is the active voice, the contraction of the Arabic sentences is clear and illustration or addition as well. Word repetitions, parallel constructions (a need to reconstruct the emphatic function of these sentences and preserve their logical structure may appear difficult for a translator but added much to the meaning. The Arabic word "وصفوه as it may have the meaning of describing or befriended as translated in the text.

Stanza (4)

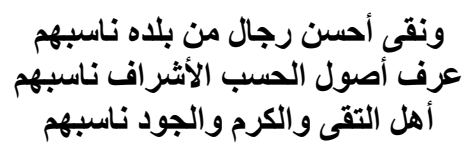

14 
A Cultural Approach to Translating the Forgotten Legacy of the Egyptian Folk, A Case study of Mawwal Badriya

Dr. Yousreya Ahmed Ali Alhamshary

مجلة وادي النيل للار اسات والبحوث الإنسانية والاجتماعية والتربوية (مجلة علمية محكمة)

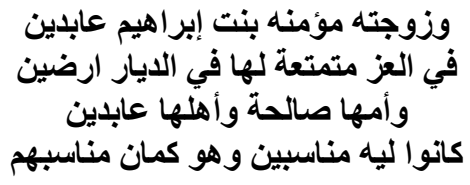

On marrying, he chose a wife from the finest family.

Knowing the noble descent, he selected the noblest family.

He married a wife from a family of piety and generosity.

Mo'mena the daughter of Ibrahim Abdeen is his wife.

She had vast lands and she enjoyed a comfortable life.

Her family name is the pious Abdeens and good is her mother.

They match him, he matches them; they suit each another.

The word "احسن, means "اشضرف اكبر " which may be translated as "noble, big, decent or fine" and all of them can be used for indicating the richness or nobility of the family. The word " وأمها صالحة و أهلها عابدين"is confusing as it may represent the adjective or the name of the family. Culturally it is not allowed for the rich woman to marry a poor man and this should be also felt from the context. The translator added the word "pious" to the word "Abdeen" to reflect the adjective not the title of the family. The expression "في العز متمتعه" is translated as "enjoyed a comfortable life" which do not give the sense of richness but goes with the context.

Stanza (5)

$$
\begin{aligned}
& \text { دي مؤمنه في الجمال مفيش مثال ليها } \\
& \text { علي العشرة مطبعه و العلم ما فارقها } \\
& \text { حُرّة ووقال الأدب ديما مفاريقها }
\end{aligned}
$$

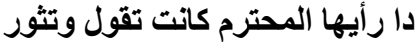

$$
\begin{aligned}
& \text { لا أدها غصن بان حلو الأوام وقصتور وتئر } \\
& \text { ووجه زي القمر لو تكثفه وتدور الأو } \\
& \text { و اللي يشوفها طول العمر ما يفارقها }
\end{aligned}
$$

Mo'mena is second to none, gorgeous and so beautiful.

She is used to abiding by fellowship .She's knowledgeable.

She's a free woman. She always speaks politely.

She expresses her opinions freely and bravely.

Tall, willowy and graceful is she;

more beautiful than Moringa tree.

With a moon-like face; if you see her,

You will never want to leave her. 
مجلة وادي النيل للاراسات والبحوث الإنسانية و الاجتماعية والتربوية (مجلة علمية محكمة)

(ISSN : 2536 - 9555)

The word "في الجمال مفيش مثال ليها" is translated by is second to none" to indicate beauty and followed by the word "knowledgeable" not "educated" because she is already not educated for women are not allowed to go to school and to suit the expression "علي العثره مطبعه" that indicates her good relationship with her surrounding people. Ironically to the Egyptian context in her time, she is brave and says her opinion freely. The expressions

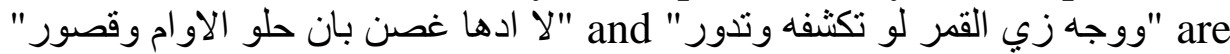
all Arabic cultural expressions indicating beauty for a girl. The translator uses " Tall, shapely and graceful is she; more beautiful than Moringa tree" to express her beauty. With a moon-like face; if you see her" to give the personal characteristics for Mo'mena. The "اوام" hord has no alternate in English thus, the translator resort to other words indicating body beauty.

Stanza (6)

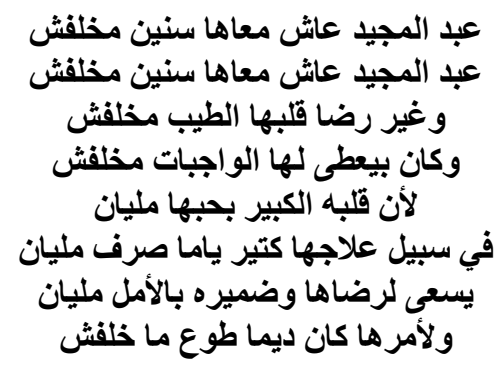

Abdel Magid has lived for years with no children

Abdel Magid has lived for years with no children

He didn't seek anything but her pleasure,

Fulfilled duties, never let her down. Never.

As her love, to the brim, filled his heart,

He spent in millions on her treatment.

Seeking her pleasure with hopeful heart

To her orders, he was a willing obedient.

The word "مخلفش is translated as "with no children" in the first line and "seek...but her pleasure" in the second line and "never" in the third line however in Arabic all may be confusing. The expression " قلبه الكبير "an is translated as "as her love to the brim filled his heart" indicating the greatness of love to her that no one else can be in his heart. The Mawwal diction here is very musical and reflective. This is clear when the singer repeated some stanzas like " عبد المجيد عاش معاها سنين" 
A Cultural Approach to Translating the Forgotten Legacy of the Egyptian Folk, A Case study of Mawwal Badriya

Dr. Yousreya Ahmed Ali Alhamshary

مجلة وادي النيل للاراسات والبحوث الإنسانية والاجتماعية والتربوية (مجلة علمية محكمة)

Abdel Magid lived for years with no children". May be this to indicate love and stable life contrasting with the culture of Egyptian personality that if she is a barren (does not give birth), he should get another wife.

Stanza (7):

Here the idea of second marriage in the Middle East which is forbidden in the west is clear.

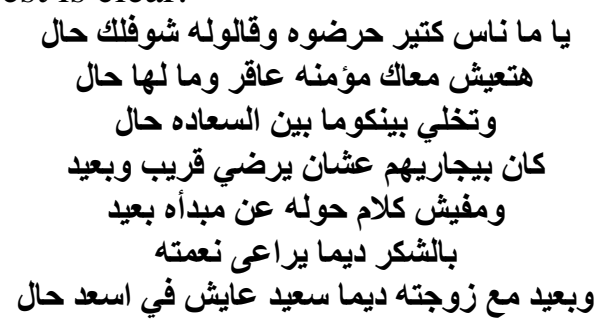

How many a time people urged him to look for a second wife.

Claiming that Mo'mena would stay with him as a barren wife.

Alleging that this might stop him from leading a happy life.

He deluded them they were right anyway.

But nothing diverted him from his way.

He was always thankful,

There he and his wife, leading the happiest life.

The word "حال in the first line indicates "a second marriage" and the in the second line and the last one meaning "status" and in the third line meaning "obstruction". The word "بعيد" in the fourth line means "other people except their relatives" and in the fifth line means "distance in thinking or place".

Grammatical parameters of a source text are little changed in the translated text Modal verbs (English modal verbs have different degrees of obligation that can be expressed with one and the same modal verb in Arabic) "Claiming that Mo'mena would stay", "That she would find him another wife". Lexical elements reflecting social and cultural peculiarities of the source culture are represented in the borrowing of some proper names like Shedid, Abdelkawi, Badreya, Abdelmageed and M'omena." 
مجلة وادي النيل للاراسات والبحوث الإنسانية والاجتماعية والتربوية (مجلة علمية محكمة)

(ISSN : 2536 - 9555)

Stanza (8)

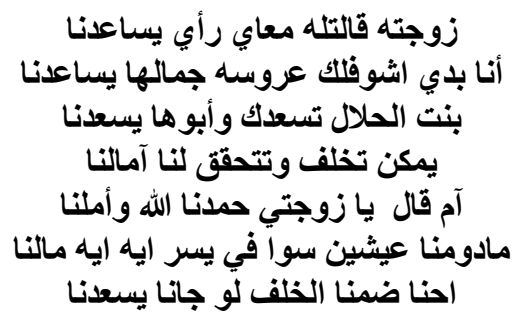

His wife once suggested

That she would find him another wife

A well-bred pretty one to bring happiness to her husband's life

"She might beget and thus our hopes will be achieved," Said his wife.

He said," we have already wished and thanked God.

As long as we now live at ease, why should we worry then?

Are we sure we would be happy if we had children?"

The culture of the society is ironically represented in this stanza where a wife can find her husband another wife. The word " بنت "حلال means well brought up and the word "امالنا" in the fourth and fifth line means "dreams" but it means "do not care about others" all words explain the good status of the husband and the wife without having children. The feeling of the wife loving her husband is represented in her offer to get him another wife but he refused for fear of being not happy as they are. All these meanings are represented in the translation but not effectively as the Arabic version.

Stanza (9)

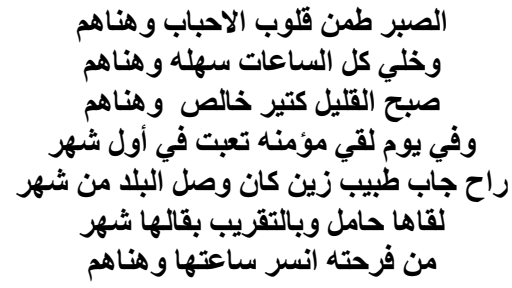

Patience calmed the hearts of the loving couples and made them pleased.

All their times became easy and they were made pleased.

In their eyes, their little income increased.

So they got pleased.

He once noticed that Mo'mena was in pain after a month.

So, he fetched a clever doctor who reached the village last month

The doctor found that she had been pregnant since last month.

He became happy and congratulated them both. 
A Cultural Approach to Translating the Forgotten Legacy of the Egyptian Folk, A Case study of Mawwal Badriya

Dr. Yousreya Ahmed Ali Alhamshary

مجلة وادي النيل للار اسات والبحوث الإنسانية والاجتماعية والتربوية (مجلة علمية محكمة)

The word "هناهم" in the first three lines is very expressive. It means "have made them happy" in all lines but with different context. It represents their status with patience. Finally she has got a baby which is in the Egyptian culture a great event for woman. It is very difficult for woman not to give birth in the society.

Stanza (10)

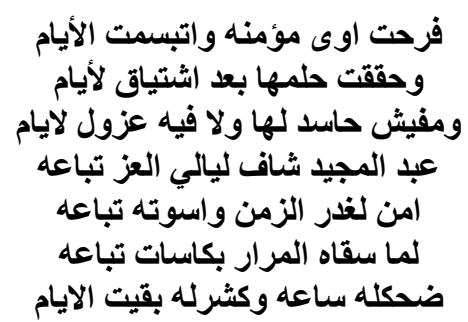

Mo'mena became so happy and pleasant were her days.

Now, her dream came true after longing for so many days.

She has no envious one nor a blamer who blames constantly

Abdel Magid witnessed the best ever led days incessantly

Safe from life calamities followed by tough times immediately

Time had caused him to suffer persistently

Time smiled for a day, but frowned at him all the other days.

The word "الايام" in the first line means "days" in the second line it means "along time" where as in the third line it means "a blaming person" and again means "days" in the last line. The word "تباعه" in the fourth, fifth and sixth line means "following each other" but with different context. The miserable life is clear now for the couples. The word "العز" in the Arabic culture may be related to richness or comfortable or stability in life. The expression "غدر الزمن واسوته translated as "Safe from life calamities followed by tough times immediately" and "سقاه المر " translated by "Time had caused him to suffer persistently" are all Arabic ones that indicate miserable life. All these feelings and contexts are represented in the translation but not strongly as the Arabic version. 
مجلة وادي النيل للاراسات والبحوث الإنسانية والاجتماعية والتربوية (مجلة علمية محكمة)

(ISSN : 2536 - 9555)

Stanza (11)

$$
\begin{aligned}
& \text { فات شهر ورا شهر بقوا تسع شهور تمت }
\end{aligned}
$$

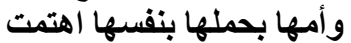

$$
\begin{aligned}
& \text { ولا تعلم إن النهاية قربت تمتهب } \\
& \text { بالسلامة قامت ووضعت بان بنتها وهنا }
\end{aligned}
$$

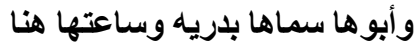

$$
\begin{aligned}
& \text { ويعد يومين وبعد يومين فاتوا في سرور وهنا وهنا } \\
& \text { ماتت خلاص مؤمنه و الفرحة ما تمت فين }
\end{aligned}
$$

A month after a month all pregnancy months have completed.

She took care of herself till pregnancy months have completed

Knowing not that her life has already completed.

Mo'mena gave birth to a baby girl safely and in bless

Her father named her Badreya. Her time is full of bliss

Two days later; two days of happiness and bliss

Mo'mena died. So their happiness hasn't completed.

The expression "بالسلامه قامت in Arabic culture means she got a baby or has done a successful operation or maybe she is well after a disease. Here it is translated as "gave birth to a baby girl safely ". Another cultural expression in the last line "الفرحه ما تمت means their happiness stopped and their life changed to a miserable one. The cultural side that a mother takes care of her pregnant daughter is represented in the second line.

Stanza (12)

$$
\begin{aligned}
& \text { ماتت الأصيلة وقابلت وجه ربها } \\
& \text { تركت لعبد المجيد طفله ورباها } \\
& \text { جعلها هي متاع دنياه ورباها } \\
& \text { وداق مرارة الزمن } \\
& \text { وداق مرارة الزمن مرن الزمن } \\
& \text { وداق مرارة الزمن لما غدر وجا مال مال } \\
& \text { في بنته بدريه صورة أمها وجمال } \\
& \text { ملت عليه دنيته بهجة وفرح وجمال } \\
& \text { وعلي الأدب والكمال والزوق رباهيا }
\end{aligned}
$$

The Noble woman died. To her Lord she went.

A baby daughter to Abdel Magid, she has left.

He brought her up seeing her life-long enjoyment.

He experienced life's bitterness

He experienced life's bitterness

He experienced life's bitterness when life frowned at him at once.

His daughter Badreya was a second copy of her mother's beauty.

She filled his life with joy, happiness and beauty.

He brought her up upon politeness and integrity. 
A Cultural Approach to Translating the Forgotten Legacy of the Egyptian Folk, A Case study of Mawwal Badriya

Dr. Yousreya Ahmed Ali Alhamshary

مجلة وادي النيل للاراسات والبحوث الإنسانية والاجتماعية والتربوية (مجلة علمية محكمة)

The expression "ماتت الاصيله وقابلت وجه ربها الزها expression "داق مرارة الزمنه "دindicates the painful time he lived. Another expression is "ملت عليه دنيته " meaning that he devoted all his time for his daughter. The translator uses "she filled his life with joy".

Stanza (13)

$$
\begin{aligned}
& \text { وهى كانت نبيهة ودرسها حفظاه } \\
& \text { الأولى على المدرسة وبختها حفظاه } \\
& \text { جعلت إيماتها دليلها والثرف حفت حفظاه }
\end{aligned}
$$

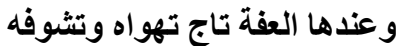

$$
\begin{aligned}
& \text { واللفظ منها دو اللجرح وتثنوفه } \\
& \text { بادلت ابوها حنان بحنان وتثنوفه } \\
& \text { بتر اعي ديما ظروفه و الجميل حافظاه }
\end{aligned}
$$

She was intelligent. And at school, she did well.

She came top of her school. She knows her way well.

She made faith her guide and she kept honor as well.

She's crowned with virtue. She kept her chastity

Her words cure one's wounds like a remedy.

She and her father reciprocated tenderness and sympathy.

She took his conditions into consideration. She acknowledges his favors well.

The expression" means that she is very inelegant and smart at school although she has no one to guide her at school. The expression "تاج العفه indicates the goodness of her character and is translated as "She's crowned with virtue. Another expression is "حافظ الجميل indicates the keeping in mind the good deeds of other people and is translated as "She acknowledges his favors well" in this context.

Stanza (14)

$$
\begin{aligned}
& \text { بدريه في كل يوم بتسافر البندر } \\
& \text { عثان تثم العلوم في مدارس البندر } \\
& \text { وتعود في القطر بعد العصر من البندر } \\
& \text { عارفه طريقها بصحيح وعن الأصول ما تمبل تميل } \\
& \text { بالليل تذاكر دروسها وعمر ها ما تميل } \\
& \text { لها حسن فتان ولغيره القلووب ما ماتميل } \\
& \text { وجمالها مالوش مثيل في الريف ولان البندر }
\end{aligned}
$$

Every day, Badreya travels to Albander to learn at the schools of the town.

By train, she comes back home in the evening from the town. 
مجلة وادي النيل للاراسات والبحوث الإنسانية والاجتماعية والتربوية (مجلة علمية محكمة)

(ISSN : 2536 - 9555)

She knows her way well. She's straight

She never swerves; she doesn't deviate.

At night she studies her lessons. From her goal she never diverted She's charming and stunning. All hearts, to her beauty, are directed.

Her beauty has no like either in the country or the town.

The word "البندر" is meant urban life in town. The translator used the Arabic name at first then used town to get it understood. The expression "عارفه طريقها بصحيح وعن الاصول ما تميل is translated as "She knows her way well. She's straight" although no big difference between the expression "knows her way and straight" in the meaning but they have another embedded meaning that her good behavious look like her values and principles. The translator used the word as it is.

Stanza (15)

$$
\begin{aligned}
& \text { كان في البلا شخص حب الماده غياته } \\
& \text { ينهب في خيرها وظلم الخا الخلق غياته } \\
& \text { اغلب مصالح البلا في ايديه غياته } \\
& \text { ومهما يعمل خطا يشكر ولا يتلام } \\
& \text { ويلاقي تثجيع ومجامله ولا يتلام } \\
& \text { عشان كده انفرد خالص ولامن وليتلام } \\
& \text { وياما طفش حمام من برج غياته }
\end{aligned}
$$

A man who has no aim but money was in the village.

He wrongs people and the properties he does pillage.

In his grip, there are most of the interests of the village.

Whatever he did, he was praised, received no blame.

To him, only encouragement and compliment came.

So, he tyrannized and then he - autocrat- became.

How many a time he expelled pigeons from their loft cage!

The word "غياته" means his desires. The word "يتلام" in the fourth and fifth lines means "no blame" but in the sixth line it means "to spread" the opposite of "dough". The expression " طفش "حمام من برج غياته "means to disturb people and push them to leave their home running away from his injustices. The word "غياته" has different meanings like "target, desire, goal, or aim". All the adjectives used in the translation indicate that he controls the village and the peoples' destiny.

Stanza (16)

$$
\text { شديد بيحب نفسه ويس وطبعها }
$$


A Cultural Approach to Translating the Forgotten Legacy of the Egyptian Folk, A Case study of Mawwal Badriya

Dr. Yousreya Ahmed Ali Alhamshary

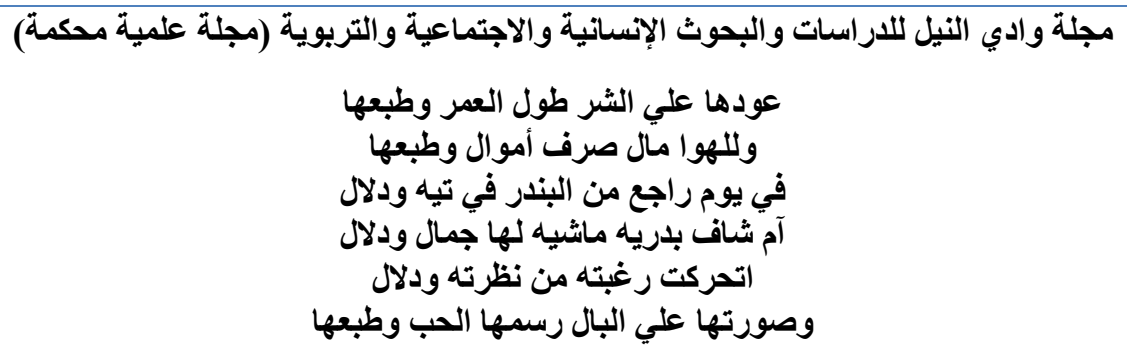

Selfish Shedid, only about himself, cared and minded.

He got used to doing evil. He was always evil-minded.

Spendthrift and a desire-follower,

corrupted and a money -forger.

As he was coming back from town drunk and haughtily,

he saw pretty Badreya walking coquettishly.

Once he saw her, he got his desire sparkle ignited.

Fell in love with her and in his heart she was printed.

The expression "تيه ودلال indicating his corruption and degeneration is translated as "drunk and haughtily". The expression " لها جمال ودلال" is impressive as it reflects the beauty and

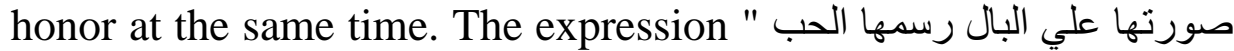
indicate the strength of love towards Badreya and translated as "he got his desire sparkle ignited". No alternate English for the word "بال" except the word "mind" but the translator used "heart" to indicate love.

Stanza (17)

$$
\begin{aligned}
& \text { قال للغفير الخصوصي قولي مين دي } \\
& \text { اللي علي خدها الورود مندى التئي }
\end{aligned}
$$

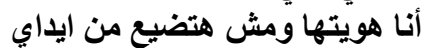

$$
\begin{aligned}
& \text { عبد القوى قال على الخياطوجرئه }
\end{aligned}
$$

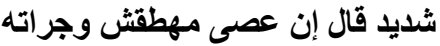

$$
\begin{aligned}
& \text { ولا ادفعلوش من دية حقطع رقبته }
\end{aligned}
$$

He asked his body guard to check if he knew that girl with rosy cheek

And told him he had loved her and he wouldn't let her go or leak.

Abdel Qawy told him about the tailor and his bald courage.

Shedid threatened if the tailor refused to give him his daughter and did challenge,

he would kill him immediately, not paying any blood indemnity. 
مجلة وادي النيل للاراسات والبحوث الإنسانية والاجتماعية والتربوية (مجلة علمية محكمة)

(ISSN : 2536 - 9555)

The expression "خدها الورد مندي" translated as "that girl with rosy cheek" indicates the beauty of badreya. The expression " مش هنضيع "خدري translated as he wouldn't let her go or leak indicates his confidence that he will have the girl whatever the circumstances are. The injustice of Shedid is very clear in the expression " حقع مقاد "رقبته و لا ادفعلوش من ديه "which means that he commits crimes without any questioning from anybody. The culture of killing and paying for the murdered person is clear in this stanza. Some terms are considered traditional equivalents that are available in English like bodyguard; "قال للغفير الخصوصي قولي مين دي", "He asked his body guard to check", if there are no such equivalents, it may hinder the process of translation. Ethnographical terminology also were used like" و لا ادفعلوش من دية حقطع رقتبه "he would kill him immediately, not paying any blood indemnity.

Stanza (18)

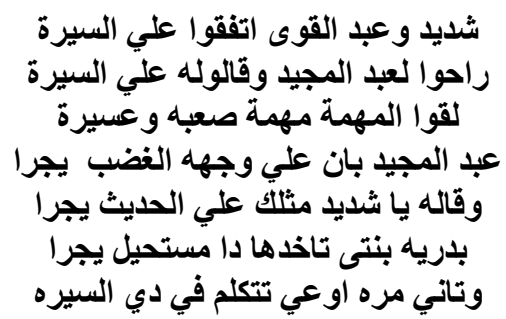

Shedid and Abdel Qawy decided to go to

Abdel Magid asking for Badryea to propose to.

Their proposal was refused. It was impossible, too.

On Abdel Magid's face, anger was so clear

He asked how Shedid did dare

to propose to Badryea to marry her

He told Shedid it was impossible to do so

and said, "Don't propose to her again. Never do"

The expression "منثل علي الحديث يجرا" translated as "did dare" means that Abdel Magid despises Shedid and sees questioning to marry his daughter as a big mistake. The challenge in Abdel Magid's talk indicates his strength in defending his daughter.

Stanza (19)

$$
\text { خمسين سنده خاف الله في مالك ومال غيال غيرك }
$$


A Cultural Approach to Translating the Forgotten Legacy of the Egyptian Folk, A Case study of Mawwal Badriya

Dr. Yousreya Ahmed Ali Alhamshary

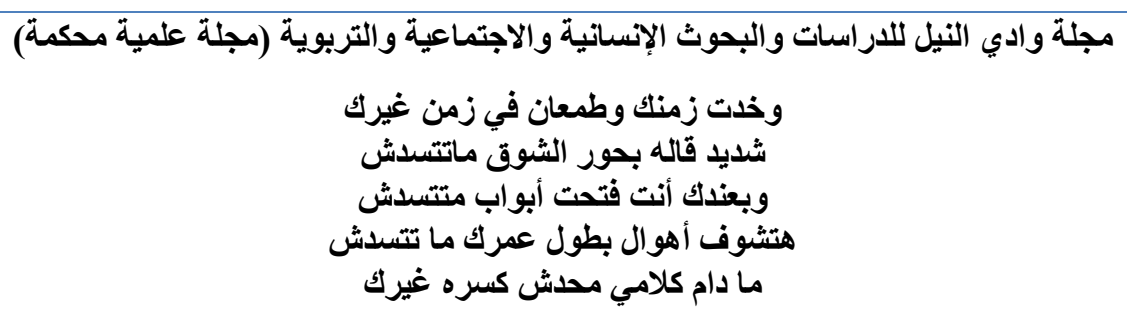

Concerning your money and the people's Fear Allah, Shedid For fifty years you, by Satan, have been misled A life full of greed and revelry you have led. Shedid replied, "I had so much longing; irresistible. And your inflexibility caused problems; not solvable.

To my punitive measures you will be vulnerable." "As nobody defied my orders but you," Shedid said.

This last stanza is very impressive as it has the same opining "خدت زمنك وطمعان في زمن غيرك" wise words. The expression indicates another difference between Shidid and Badreya which is age. The expression "بحور الثوق" translated as "I had so much longing; irresistible" only mentioned in the Arabic poetry and indicates a great love Shidid has to Badreya. The expression " فتحت "translated as "And your inflexibility caused problems; not solvable" indicates that Shedid is going to fight for Badreyea causing "اهوال بطول عمرك" translated as " To my punitive

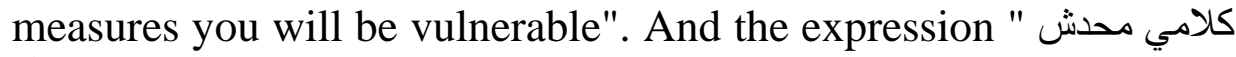
translated as "As nobody defied my orders but you" indicates the endless battle between Shedid and Abdel Magid. There is a shift in feeling, for example he was narrating about the social life of Shedid's family then moved to the political situation and government corruption and the injustice life people live in, the reader should follow this shift in the translated text. He gives advice in his story problem in particular but actually he refers to the general society. Shedid representing the government is not honest but deceives people.

The name of the folk itself is very impressive. It was known about the Egyptian society at that time that man controls the society like Sielsayed ironically Abdelmegeed loves the mother then loves the daughter and protects both of them from social violence. He was keen not to harm his wife's feeling by marrying 
another one besides educating his daughter even if she goes out the village. His loyalty to his wife is impressive where he should marry to have a child but sacrifices his desire and accepted Allah's fat and after death he did not marry and get a mother in low for his daughter. All these social values are needed nowadays to have a strong society without social diseases. Abdel Megid by doing this is giving a great example for the aware Arabic man who appreciates women in family life. The names of the story also are impressive and have indications in the Arabic culture where Abdel Mgid is indicating a religious person and clear and good character. Mo'mena also represents the woman who is patient and satisfied with God's giving and waiting his grant (having a child). Shedid is representing the aggressive and injustice character. Badreya also has a symbolic name where it refers to the beauty and magic face like (albadr or moon).

The Mawwal sequence shows the development of the story where it begins with the parents. The writer uses the seven line stanza of writing except the first one used the four line stanza. May be because it is the starting point of the story to give imagination and catch more attention. Badreya is supposed to express the feelings of all Egyptian readers or listeners and may be the translation led to another vision or image in their minds. Translators should be aware of the culture to get the right image.

\section{Results}

A song (here means the Mawwal) is a type of text written in the same pattern as poetry, which Nida (1964) states is "poetry set to music". Translation of song lyrics is complicated because it requires the translator to make choices of words that match with the number of notes, the rhythm, the music, and to be aware of the length of the song phrases (George, 2004). Lyrics are poetry like written and the principles relating to poetry and its translation can be regarded as a useful reference for the translation of songs. Poetry is written chiefly to express a poet's state of mind or reaction toward a situation that the poet has encountered rather than giving information or narrating a situation. Here, it is not the poet's status, the singer or even the narrator only but the Mawwal 
A Cultural Approach to Translating the Forgotten Legacy of the Egyptian Folk, A Case study of Mawwal Badriya

Dr. Yousreya Ahmed Ali Alhamshary

مجلة وادي النيل للاراسات والبحوث الإنسانية والاجتماعية والتربوية (مجلة علمية محكمة)

is representing the whole society's one. However there is a difference between poetry and this type text as poetry needs a welleducated person to listen to or evaluate but the Mawwal is listened to or be read by all literate or illiterate people. This indicates why it is directed to the low class people which form more than half of the society. In translating the Arabic lines, the translator was committed to three items namely semantic meaning, Arabic rhyme and structure of lines. Based on Baker (1992) strategies for translating a task, the researcher resorted to strategies including:

a) Translation by a more general word (super ordinate):

This strategy works appropriately in most languages, because meaning is not language dependent in the semantic field. Thus, it is a common strategy in dealing with different types of nonequivalence. For example:

On marrying, he chose a wife from the finest family.

Knowing the noble descent, he selected the noblest family.

He married a wife from a family of piety and generosity.

The goal here is to indicate the good qualities of his wife and the noble position of her family. Or in stanza (5) saying:

She's a free woman. She always speaks politely.

She expresses her opinions freely and bravely.

The goal of the text is only to indicate the characteristics of the wife. Or in stanza (6) saying:

Seeking her pleasure with hopeful heart

To her orders, he was a willing obedient.

Or in stanza (10) saying:

Safe from life calamities followed by tough times immediately

Time had caused him to suffer persistently

Time smiled for a day, but frowned at him all the other days.

b)Translation by a more neutral/less expressive word,

This is the second strategy used also in the semantic field of structure. For example:

Tall, shapely and graceful is she;

more beautiful than Moringa tree.

With a moon-like face; if you see her,

You will never want to leave her. 
مجلة وادي النيل للاراسات والبحوث الإنسانية و الاجتماعية والتربوية (مجلة علمية محكمة)

(ISSN : 2536 - 9555)

In this stanza lines the researcher describes the beauty of MO'mena like the Moringa tree to be natural as the tree.

c) Translation using a loan word or loan word plus explanation

This strategy is usually used in dealing with culture-specific items, modern concepts, or buzz words. It is very useful when a word is repeated many times in the text. The word is mentioned at the first place by the explanation and when repeated it may be used by its own. This is used with translating the proper nouns all over the Mawwal like Mr Abdel Magid, Mo'mena, Ibrahim Abdeen, Moringa tree, Badreya, Abdel Qawy, Shedid or even Albander.

\section{d) Translation by cultural substitution,}

This strategy is based on replacing a culture-specific expression in the source text with a target language expression considering its impact on reader or listener and making the translated text more familiar, more natural, more understandable to readers. For example the use of expression "Mr" from the English culture to refer to a man.

e) Translation by paraphrase using a related word,

This strategy is used when the source word is lexicalized in the target language but in a different form in which the translator can use them as alternate for the word. For example in stanza (3)

From his shop a groom is advised to buy the dress for his bride;

At every wedding night he invites people and he accepts their invitation.

He befriended them with his good soul; And likewise they befriended him all.

The interaction or the exchanging feeling between Abdel Megid and the people expressed in "invites people" and accepts their invitation" or the expression of "befriended them" and "be friended him" to indicate same relationship. Another example in stanza (5) describing Mo'mena:

Tall, shapely and graceful is she;

more beautiful than Moringa tree.

With a moon-like face; if you see her, 
A Cultural Approach to Translating the Forgotten Legacy of the Egyptian Folk, A Case study of Mawwal Badriya

Dr. Yousreya Ahmed Ali Alhamshary

مجلة وادي النيل للاراسات والبحوث الإنسانية والاجتماعية والتربوية (مجلة علمية محكمة)

You will never want to leave her.

Another example is in Stanza (15), describing shedid's character and relation with the people of the town.

So, he tyrannized and then he - autocrat- became.

How many a time he expelled pigeons from their loft cage!

Generally speaking this strategy is used when using metaphors or similes in the Arabic version. More examples are included in the translation.

f) Translation by paraphrase using unrelated words,

This strategy can be used when the concept in the source item is not lexicalized or when the meaning of the source item is complex in the target language, this strategy may be used based on modifying a super-ordinate or simply clarifying the meaning of the source item. This strategy is found in stanza seven saying "He deluded them they were right anyway." to indicate Abdel Megid's insistence to continue his personal life and be stable. Another example in stanza (14):

She knows her way well. She's straight

She never swerves; she doesn't deviate.

\section{g) Translation by illustration /addition as illustrated previously.}

This strategy is useful when the target equivalent item does not cover aspects of the source item or the equivalent item refers to a physical entity that can be illustrated. For example in stanza (2):

He has nothing but a house with a shop where there's a sewing machine to help. Amongst people he protects his dignity.

Or in stanza (3) when saying:

dresses with silky hand-made laces with nice decoration.

His gain was his parents' pleasure and their invocation.

\section{h) Translation by omission}

This strategy is useful in case of welling to omit the unnecessary word or expression in contexts, if the meaning conveyed is understandable, and also is used to avoid lengthy explanations and be concise and to the point. For example omission of the possessive pronoun in "True that God is forgiving 
مجلة وادي النيل للاراسات والبحوث الإنسانية والاجتماعية والتربوية (مجلة علمية محكمة)

(ISSN : 2536 - 9555)

yet" to indicate generalization as God is for all not only for the speaker. Another example in stanza three saying "Sweet are his words; Like sherbet of high quality" for the expression " روقوه "ولقو أهل التقى " Another example in stanza four is the omission of "as the previous "he selected the noblest family" includes all noble adjectives and no need for the other expression for it will not add to the meaning. The eight strategies of Baker are recurrent in the Mawwal and the following table represents the frequencies of each one.

Table (1): Frequencies of strategies in translating the Mawwal.

\begin{tabular}{|l|l|l|l|l|l|l|l|l|l|l|l|l|l|l|l|l|l|l|l|}
\hline $\begin{array}{l}\text { Stanzas } \\
\text { Strategy }\end{array}$ & $\mathbf{1}$ & $\mathbf{2}$ & $\mathbf{3}$ & $\mathbf{4}$ & $\mathbf{5}$ & $\mathbf{6}$ & $\mathbf{7}$ & $\mathbf{8}$ & $\mathbf{9}$ & $\mathbf{1 0}$ & $\mathbf{1 1}$ & $\mathbf{1 2}$ & $\mathbf{1 3}$ & $\mathbf{1 4}$ & $\mathbf{1 5}$ & $\mathbf{1 6}$ & $\mathbf{1 7}$ & $\mathbf{1 8}$ & $\mathbf{1 9}$ \\
\hline $\begin{array}{l}\text { General } \\
\text { words }\end{array}$ & & $*$ & & $*$ & $*$ & $*$ & & & & $*$ & & & & & & & & & \\
\hline $\begin{array}{l}\text { Neutral/less } \\
\text { expressive }\end{array}$ & & $*$ & & & $*$ & & & & & & & & $*$ & & & & $*$ & & \\
\hline Loan words & $*$ & $*$ & & $*$ & $*$ & $*$ & & & $*$ & $*$ & & $*$ & & $*$ & & $*$ & $*$ & $*$ & $*$ \\
\hline $\begin{array}{l}\text { Cultural } \\
\text { substitutions }\end{array}$ & $*$ & $*$ & & & $*$ & & & & & & & & & & & & & & \\
\hline $\begin{array}{l}\text { Paraphrasing } \\
\text { with related } \\
\text { words }\end{array}$ & $*$ & $*$ & & $*$ & $*$ & $*$ & $*$ & $*$ & & $*$ & $*$ & $*$ & $*$ & $*$ & $*$ & & & \\
\hline $\begin{array}{l}\text { Paraphrasing } \\
\text { with } \\
\text { unrelated } \\
\text { words }\end{array}$ & & $*$ & $*$ & & $*$ & $*$ & $*$ & & $*$ & & & $*$ & $*$ & $*$ & $*$ & $*$ & & & \\
\hline $\begin{array}{l}\text { Addition } \\
\text { illustration }\end{array}$ & & $*$ & $*$ & & $*$ & $*$ & $*$ & $*$ & $*$ & & $*$ & $*$ & $*$ & $*$ & $*$ & $*$ & & & \\
\hline Omission & $*$ & & $*$ & $*$ & & & & & & & & & & & & & & & \\
\hline
\end{tabular}

The table shows that the most frequent strategy is the loan of words for proper nouns are repeated all over the Mawwal. Whereas the second one is paraphrasing using related words for being used (13) times followed by paraphrasing using unrelated words used (11) times. However, illustration or explanation are used (13) times. The highest frequency percentage indicates that there are problems in translating the Mawwal.

This framework appears to be appropriate and distinguishing framework for including the most applicable set of strategies used by professional translators and can be tested by them to evaluate to what extent they work if at all. For example, the application of translation by omission can be useful to avoid making an extensive translation in the song phrase. When it comes to culture-specific 
A Cultural Approach to Translating the Forgotten Legacy of the Egyptian Folk, A Case study of Mawwal Badriya

Dr. Yousreya Ahmed Ali Alhamshary

مجلة وادي النيل للاراسات و البحوث الإنسانية والاجتماعية والتربوية (مجلة علمية محكمة)

items or newly introduced concepts in song lyrics, translation by using a loan word or loan word plus explanation can be applied. The applications of translation by paraphrase using a related word, or paraphrase using unrelated words provide plausible ways to choose appropriate words.

Part of the difficulty in translating cultural terms like these lies in the fact that these words require a deep full knowledge and understanding of the Arabic culture; with all its social values and environmental traditions in addition to the English culture too. Besides, these words represent concepts which may not exist in English. The dictionary equivalents for these terms are either long or less explanation of their concepts. They are translated by using the paraphrase strategy where the words are explained by the nearest expressions to the meaning. In spite of excellent knowledge of both source and target language that includes proficiency in grammar, spelling, punctuation and pronunciation; socio-linguistic the translator uses the most appropriate equivalence to be understandable in the target text. Further, there are some certain words or expressions and even idioms that are unknown in the source language for foreigners as previously discussed. These unknown words and expressions directly connect to particular thoughts, religions, or people's special perspective about the world in the source language. According to Baker and Saldanha (2011, p.18) "the source-language word may express a concept which is totally unknown in the target culture. The concept in question may be abstract or concrete; it may relate to a religious belief, a social costume, or even a type of food. Such concepts are often referred to as "culture-specific". Another important factor in translating process of culture specific items is translators must have been scrupulous about the readers in the target text, because there are different educational, political, nationalities etc, levels of knowledge processing in a society, so translation should be vastly understandable. They suggest two main strategies to overcome such a difficulty. One of the commonest strategies to translate culture specific-items is the use of a general word in the translating 
(ISSN : 2536 - 9555)

process for dealing with many types of non-equivalence, particularly in the area of propositional meaning (ibid 2011). It is worthy to point out that the English language often makes distinction between different types of facilities; however, in Arabic there is no such a distinction. Thus, the researcher generalizes the concept and change to known one into the target language.

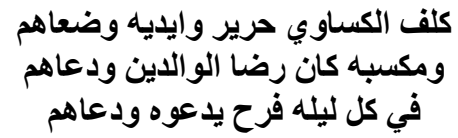

dresses with silky hand-made laces with nice decoration.

His gain was his parents' pleasure and their invocation.

At every wedding night he invites people and he accepts their invitation.

In sum, translation equivalence at the word level can be applicable to find possible equivalents in order to make choices of words that match with the number of notes, the rhythm, the music, and the length of the song phrase. The study is expected to provide valuable information in regard to the study of the translation of song lyrics, and to formulate some problems related to the translation of this type of literary work. The following are some common types of non-equivalence at word level, with examples from the Arabic text Mawwal related to culture-specific concepts. The source-language word may express a concept which is totally unknown in the target culture. The concept in question may be abstract or concrete; it may relate to a religious belief, a social custom or even a type of food. Such concepts are often referred to as "culture-specific". Some culture-specific words in the Mawwal can be summarized as follows:

- Osta: a word said to any one professional in his work.

- Dokan: a shop, supermarket or place for commercial purposes.

- Sharbat: a sweet drink for happy occasions only

- Ghosn ban: indicating gracefulness

- Add: also indicating beauty

- Alawam: body in best size 
A Cultural Approach to Translating the Forgotten Legacy of the Egyptian Folk, A Case study of Mawwal Badriya

Dr. Yousreya Ahmed Ali Alhamshary

مجلة وادي النيل للاراسات والبحوث الإنسانية والاجتماعية والتربوية (مجلة علمية محكمة)

- Bent halal: a women with all good characteristics

- Hanahom: happiness or felling satisfied or relaxed in life.

- Azoul: people who hate goodness for others

- Almor: pain, sadness, any discomfort circumstances.

- Alzaman mal: problems in life

- Adab or kamal: people with good behavior

- Efa : being with good reputation

- Dalal: felling proud of himself

- Bal : imagination

Baker and Saladanha (2011) believe difference in expressive meaning is usually more difficult to handle when the target language equivalent is more emotionally loaded than the source language item. They add, this is often the case with items which related to sensitive issues such as religion, politics and sex. Ironically, in the present case where the source language is full of emotional expressions that is very difficult when expressed in English like:

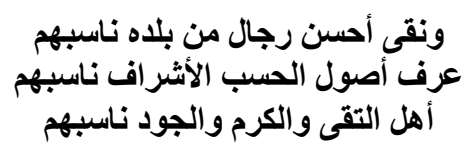

On marrying, he chose a wife from the finest family.

Knowing the noble descent, he selected the noblest family.

He married a wife from a family of piety and generosity.

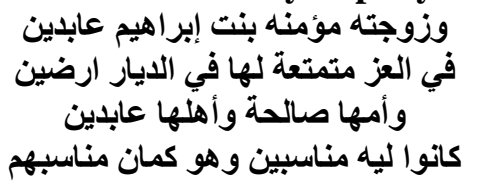

Mo'mena the daughter of Ibrahim Abdeen is his wife.

She had vast lands and she enjoyed a comfortable life.

Her family name is the pious Abdeens and good is her mother.

They match him, he matches them; they suit each another.

To overcome such difficulty translators benefit the modifier to demonstrate the significance of the given words in the source language. "In other words, if the target-language equivalent is neutral compared to the source-language item, the translator can sometimes add the evaluate element by means of a modifier or 
adverb if necessary, or by building it in somewhere else in the text" (Baker \& Saldanha, 2011, p. 21). For example a lot of adjectives, adverbs and phrases are used from the beginning till the end like:

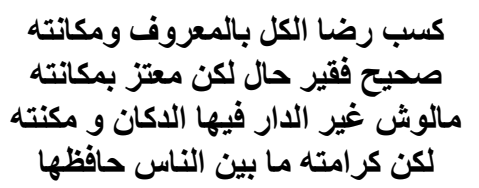

He is admired by all for his favors and dignity

It's true he is poor but he's proud of his dignity

He has nothing but a house with a shop

where there's a sewing machine to help.

Amongst people he protects his dignity.

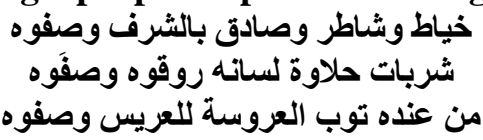

He's a clever tailor; truthful and known for honesty.

Sweet are his words; Like sherbet of high quality.

From his shop a groom is advised

to buy the dress for his bride;

The source language word may be semantically complex. This is fairly common problem in translation dealing with cultural aspects. Words do not have to be morphologically complex to be semantically complex. Thus, findings of this research can be summarized as follows:

a. This type of art is very important and has a very good impact upon social life for having a lot of values that can be represented using the colloquial language. Thus, translating Mawwal is very important to reflect on social life of Egypt for the outside world.

b. Being directed to a very big part of the society by using colloquial language has given it the place of being first effective way to direct the whole society. A lot of people listen and even push others to listen by force in traffics and taxies.

c. The society needs such values and principles presented in Badreya to get back to normal social life. Consequently, emerge the importance of revival of such a great art. 
A Cultural Approach to Translating the Forgotten Legacy of the Egyptian Folk, A Case study of Mawwal Badriya

Dr. Yousreya Ahmed Ali Alhamshary

مجلة وادي النيل للاراسات والبحوث الإنسانية والاجتماعية والتربوية (مجلة علمية محكمة)

d. The researcher uses the eight strategies of the adopted framework namely include translation by a more general word (superordinate), translation by a more neutral/less expressive word, translation by cultural substitution, translation by using a loan word or loan word plus explanation, translation by paraphrase using a related word, translation by paraphrase using unrelated words, translation by omission, and translation by illustration as shown during discussion.

e. Many types of difficulties are found but the clearest ones are related to the cultural part and the researcher tries to handle them appropriately.

\section{Conclusion}

From the forgoing analysis, discussion, results and findings, it can be deduced that the difference between Arabic and English in language use and the gab in their cultures make the process of translation a real challenge. The Mawwal contains a lot of wise words and messages from social life and to understand these messages and give appropriate meaning; there are some difficulties such as: word equivalence, sentence structure, aspect and culture specific-concepts, and difference in expressive meanings at word level. This study has identified some of the difficulties in rendering Arabic culture-bound terms in the Mawwal into English. A key concept to be considered is a perfect knowledge in both source language and target language to gain accepted translated equivalence. This paper tries to justify and prove the need for further research in this topic from the theory and practice of translation related to culture and social context. For this art is very important for social identity and values, other issues that may deserve closer analysis in the future are the focus of Mawwal language development, the translation of affixes or morphological fold are needed in the same area. The oral performance for the Mawwal is another point that should be considered in research. Generally speaking, if cultural differences do exist among languages, it is difficult, if not impossible to achieve appropriate 
مجلة وادي النيل للاراسات والبحوث الإنسانية والاجتماعية والتربوية (مجلة علمية محكمة)

(ISSN : 2536 - 9555)

transfer. For Literary translation can be regarded a means of providing an alternative or subversion of reality, any variation from the source language (SL) cultural term can be considered an act of subversion against the culture it represents even if it is very slight one.

\section{References}

- Abdelaa. N and Rashid. S (2015). Semantic Loss in the Holy Qur'an Translation with Special Reference to Surah AlWaqiAAa (Chapter of The Event Inevitable) SAGE Open October-December: 1-10 DOI: 10.1177/2158244015605880 sgo.sagepub.com

- Amjad. A. (2013). Problems and Strategies in English Translation of Qur'aanic Divine Names International Journal of Linguistics, 5(1),128-142. ISSN1948-5425

- Baker, M. (1992). In Other Words: A Course book on Translation. $3^{\text {rd }}$ ed. London: Routledge.

- Baker, M. and Saldanha, G. (2011) Routledge Encyclopedia of Translation Studies ( $2^{\text {nd }}$ ed.). Great Britain: CPI Antony Rowe, Chippenham, Wiltshire.

- Bassnett, S. (2002). Translation Studies. Great Britain: TJ International Ltd,

- Padstow, C. (2014). Disney Song Lyrics. [Online]. Available http://www.disneyclips.com/lyrics/.

- Bassnet, S. and Lefevere, A. (eds.) (1990). Translation, History and Culture. London: Pinter Publishers.

- Braçaj, M. (2015) Procedures of Translating Culture-Specific Concepts, Mediterranean Journal of Social Sciences, 6(1)s1.467-480.

- Catford, J (1965). A Linguistic Theory of Translation Oxford Univ. Press 
A Cultural Approach to Translating the Forgotten Legacy of the Egyptian Folk, A Case study of Mawwal Badriya

Dr. Yousreya Ahmed Ali Alhamshary

مجلة وادي النيل للار اسات والبحوث الإنسانية والاجتماعية والتربوية (مجلة علمية محكمة)

- Daoud . J. (2017). Equivalence Problems in Translation. SinoUS English Teaching, 14(2), 86-97 doi:10.17265/15398072/2017.02.003

- George, S. (2004). Visual Perception of Music Notation: Online and Off-line Recognition. The United of America: IRM Press.

- Hardwick, L. (2004). Translating Words, Translating Cultures. Classical Inter/Faces. London, U.K.: Duckworth.

- Kashgary, M. (2011). The Paradox of Translating the Untranslatable: Equivalence vs. Non-equivalence in Translating from Arabic into English. Journal of King Saud University - Languages and Translation. 23, 47-57

- Kenner, H. (1971). The Pound Era. Berkeley, CA: University of California Press.

- Lefevere, A (2000). "Mother Courage's Cucumbers: Text, System and Refraction in a Theory of Literature" in. Lawrence Venuti (ed) The Translation Studies Reader. London: Routledge, pp. 233-250

- Nida, E. (1964). Toward a Science of Translating: With Special Reference to Principles and Procedures Involved in Bible Translating. Leiden: Brill.

- Nida, E. and Taber, C. (1982). The Theory and Practice of Translation. Leiden: Brill.

- Newmark, P. (1991). About Translation: Multilingual Matters. Clevedon, Philadelphia, Adelaide: Multilingual Matters Ltd.

- Raffel, B. (1988). The Art of Translating Poetry. The United States of America: the Pennsylvania State University Press.

- Toury, G. (1995) Descriptive Translation Studies and Beyond, John Benjamins Publishing Company, Amsterdam. 
مجلة وادي النيل للار اسات والبحوث الإنسانية والاجتماعية والتربوية (مجلة علمية محكمة)

(ISSN : 2536 - 9555)

\section{Arabic Bibliography}

• نعمات احمد فؤاد (1989) شخصية مصر، ط5، الهيئة العامة للكتاب، القاهرة:

مؤسسة الأهرام للنشر والطبع.

\section{Websites}

- https://www.youtube.com/watch?v=Uy017sJ-vUg 